\title{
A Look at 2018 \\ Takeaway Points from the State of the Climate Supplement
}

\author{
J. BLunden And D. S. ARndt
}

\begin{abstract}
The following salient events and trends are reported upon in greater depth in the
State of the Climate in 2018, the supplement to this issue of BAMS. Figures

shown here are drawn from the supplement and are not cited in the text below.
\end{abstract}

GLOBAL CLIMATE. With a weak La Niña at the beginning of the year transitioning to weak El Niño conditions by the end in the central and eastern equatorial Pacific Ocean, the annual global temperature across land and ocean surfaces for 2018 was the fourth highest since records began in the mid-to-late 1800 s, at $0.30^{\circ}-0.40^{\circ} \mathrm{C}$ above the $1981-2010$ average, according to four independent datasets. Only the immediate preceding years of 2015, 2016, and 2017 were warmer. Every year since the start of the twenty-first century has been warmer than the 1981-2010 average. Above Earth's surface, the annual lower troposphere temperature was third to seventh highest according to the datasets analyzed. The lower stratospheric temperature was approximately fifth coldest.

In 2018, the dominant greenhouse gases released into Earth's atmosphere-carbon dioxide, methane, and nitrous oxide - continued to increase and reach new record highs. The annual global average carbon

AfFiliations: BLUNDEN AND ARNDT-NOAA/NESDIS/ National Centers for Environmental Information, Asheville, North Carolina CORRESPONDING AUTHOR: Jessica Blunden, jessica.blunden@noaa.gov

DOI:10.II75/BAMS-D-19-0193.I

In final form 5 July 2019

For information regarding reuse of this content and general copyright information, consult the AMS Copyright Policy. dioxide concentration at Earth's surface rose to 407.4 $\pm 0.1 \mathrm{ppm}$, the highest in the modern atmospheric measurement record and in ice core records dating back as far as 800,000 years. This is an increase of 2.4 $\pm 0.1 \mathrm{ppm}$ compared to 2017, similar to the average rate of increase over the past decade. Globally averaged methane $\left(\mathrm{CH}_{4}\right)$ was $1858.5 \pm 0.8 \mathrm{ppb}$, an 8.9 $\pm 0.9 \mathrm{ppb}$ increase compared to 2017 , which is higher than the average growth rate over the past decade, while nitrous oxide was $330.9 \pm 0.1 \mathrm{ppb}$, an increase of $1.1 \pm 0.2 \mathrm{ppb}$ from 2017. Combined, these greenhouse gases plus several halogenated gases contribute just over $3 \mathrm{~W} \mathrm{~m}^{-2}$ to radiative forcing and represent a nearly $43 \%$ increase since 1990 . Carbon dioxide is responsible for about $65 \%$ of this radiative forcing.

Preliminary data indicate that glaciers across the world continued to lose mass for the 30th consecutive year. For the 25 reporting glaciers, only one reported a positive mass balance for the year. Since 1980, the cumulative loss is the equivalent of slicing $24 \mathrm{~m}$ off the top of the average glacier. In contrast, snow cover over North America and Eurasia in 2018 was above average in both spring and autumn, but it is still trending overall toward below-average extent during May and June, when snow melt is most prevalent.

Globally, the levels of fire activity during 2018 were the lowest since the start of the record in 1997, with a combined burned area of about 500 million hectares. The low fire year is consistent with the long-term downward trend in fire emissions, which has been driven primarily by the conversion of frequently 


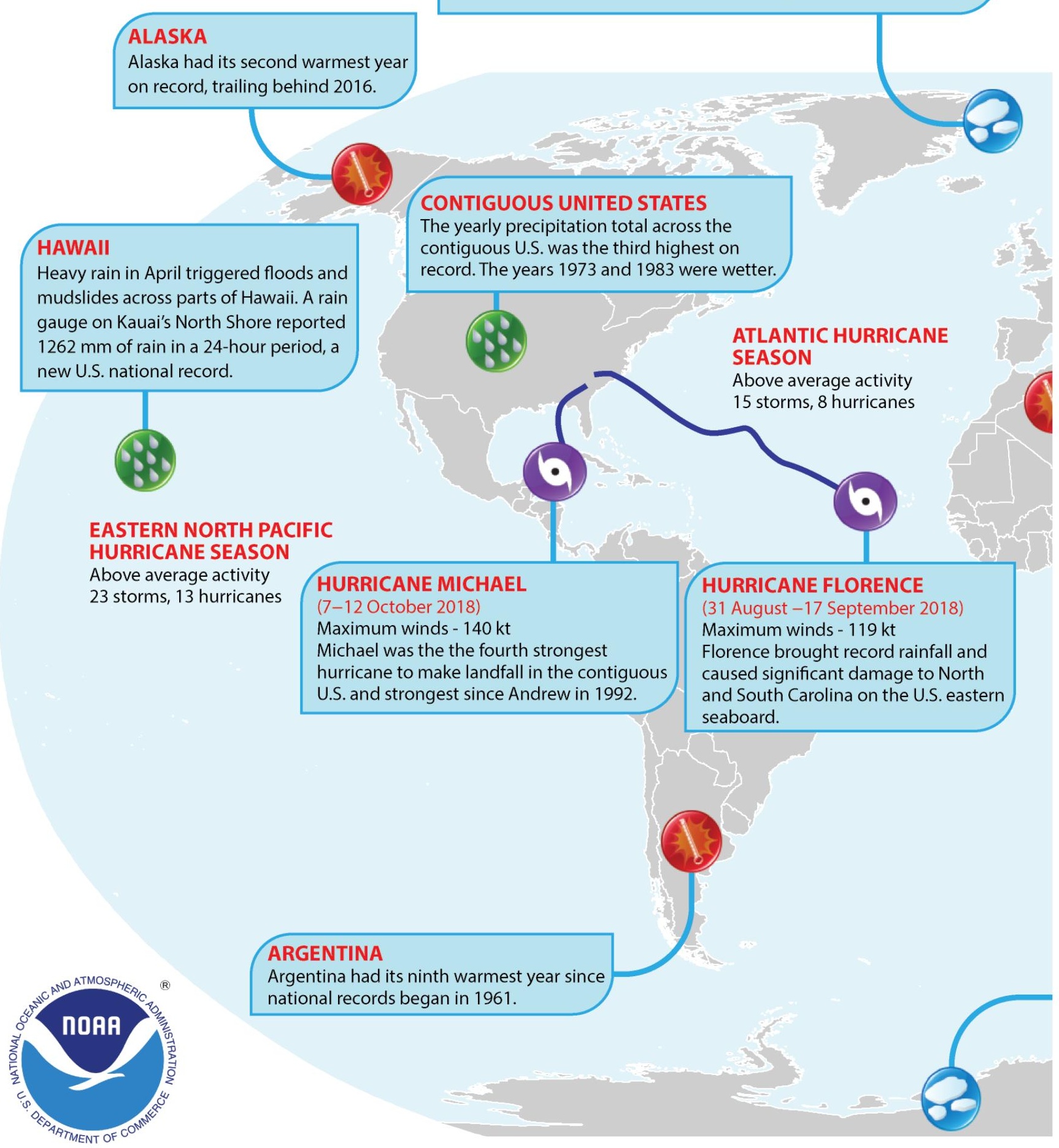

Geographical distribution of selected notable climate anomalies and events in 2018. (Figure I.I from State of the Climate in 2018.) 


\section{EUROPE}

Much-warmer-than-average conditions engulfed much of Europe for most of 2018, resulting in its second warmest year on record. Several countries had a record or near-record warm year, including France, Italy, Serbia, Croatia, Greece, and Bosnia and Herzegovina.

\section{PAKISTAN

Nawabshah, in southern Sindh province, recorded a temperature of $50.2^{\circ} \mathrm{C}$ on $30 \mathrm{April}$, a preliminary world temperature record for April.

\section{ALGERIA}

On July 5 , the city of Ouargla recorded a maximum temperature of $51.3^{\circ} \mathrm{C}\left(124.3^{\circ} \mathrm{F}\right)$, the highest temperature ever recorded in Algeria.

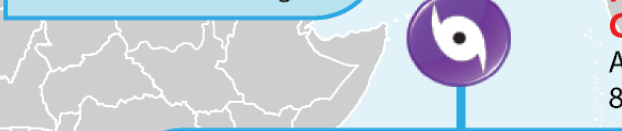

\section{CYCLONE MEKUNU \\ (22-26 May 2018)}

Maximum winds $-100 \mathrm{kt}$

The strongest cylcone to make landfall in the Arabian Sea. Salalah, Oman, received over five times its annual average precipitation in a 96-hour period.

\section{SOUTH INDIAN OCEAN CYCLONE SEASON} Above average activity 10 storms, 7 cyclones

\section{AUSTRALIA}

AUSTRALIAN CYCLONE

\section{SEASON}

Average activity

11 storms, 6 cyclones

Australia had its third warmest year since national records began in 1910 .

\section{ANTARCTIC SEA ICE EXTENT}

During its growth season, the Antarctic had its fourth smallest annual maximum extent. During its melt season, the Antarctic reached its second smallest minimum extent on record.

\section{NEW ZEALAND}

The 2018 national temperature for New Zealand tied with 1998 as the second highest temperature on record, behind 2016.

Please Note: Material provided in this map was compiled from NOAA's NCEI State of the Climate Reports, the WMO Statement on the State of the Global Climate in 2018, and authorship for this report. For more information please visit: http://www.ncdc.noaa.gov/sotc. 
burning savannas to agricultural areas. Regionally, northern hemispheric Africa and South America each experienced their lowest annual fire activities, while North America and Australia had fire emissions that were higher than normal.

\section{Rising lake temperatures around the world}

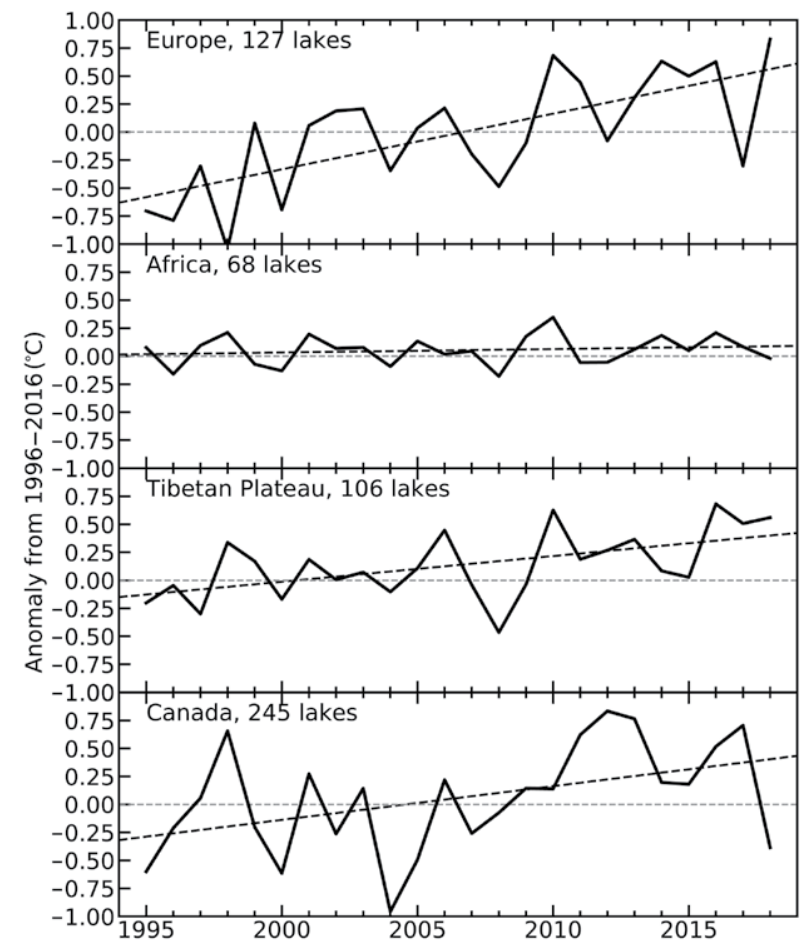

As the globe warms, so too do its lakes, albeit with distinctions among major regions and continents. Satellite observations reveal that European lakes are among the fastest warming over the last quarter century. (Figure 2.3 from State of the Climate in 2018, see discussion there in section $2 c$.)
GLOBAL OCEANS. Across the oceans, globally averaged sea surface temperature (SST) cooled slightly since the record El Niño year of 2016 but was still far above the $1981-2010$ mean by $0.33^{\circ} \pm 0.05^{\circ} \mathrm{C}$ in 2018. On average, SST has been increasing at a rate of $0.10^{\circ} \pm 0.01^{\circ} \mathrm{C}$ per decade since 1950 . The warming appeared largest in the tropical Indian Ocean and smallest in the North Pacific.

For the seventh consecutive year, global annual mean sea level (GMSL) reached a new record high for the 26-year satellite altimetry record, rising to $81 \mathrm{~mm}$ above the 1993 average. The new high reflects an ongoing trend of $3.1 \pm 0.4 \mathrm{~mm} \mathrm{yr}^{-1}$. Sea level change can, however, vary greatly by region. Multiple regions around the global ocean have experienced a rise of 150-200 mm during this period. Ongoing trends and year-to-year changes in sea level impact coastal communities by increasing the magnitude and frequency of positive sea level extremes that cause flooding and erosion.

Over the last decade, the global ocean has continued to take up a substantial fraction of anthropogenic carbon (C) emissions, and thus is a major mediator of global climate change. During 2008-17, about $22 \%$ of the anthropogenic carbon released into the atmosphere has accumulated in the ocean. Over time, this uptake by the ocean has grown from $1.0( \pm 0.5) \mathrm{Pg} \mathrm{C}_{\mathrm{yr}}^{-1}$ in the 1960 s to $2.5( \pm 0.5) \mathrm{Pg} \mathrm{C} \mathrm{yr}^{-1}$ in 2017. It is estimated that the ocean uptake of anthropogenic carbon was $3.1 \mathrm{Pg} \mathrm{C}$ for 2018 compared to $2.6 \mathrm{Pg} \mathrm{C}$ in 2017 . This increase is well within the overall expectation that the ocean will remain an increasing sink as long as atmospheric carbon dioxide levels continue to rise. The sequestration of carbon dioxide by the ocean partially mitigates the atmospheric carbon dioxide rise, but it comes

\section{Record high global ocean heat content in $\mathbf{2 0 1 8}$}

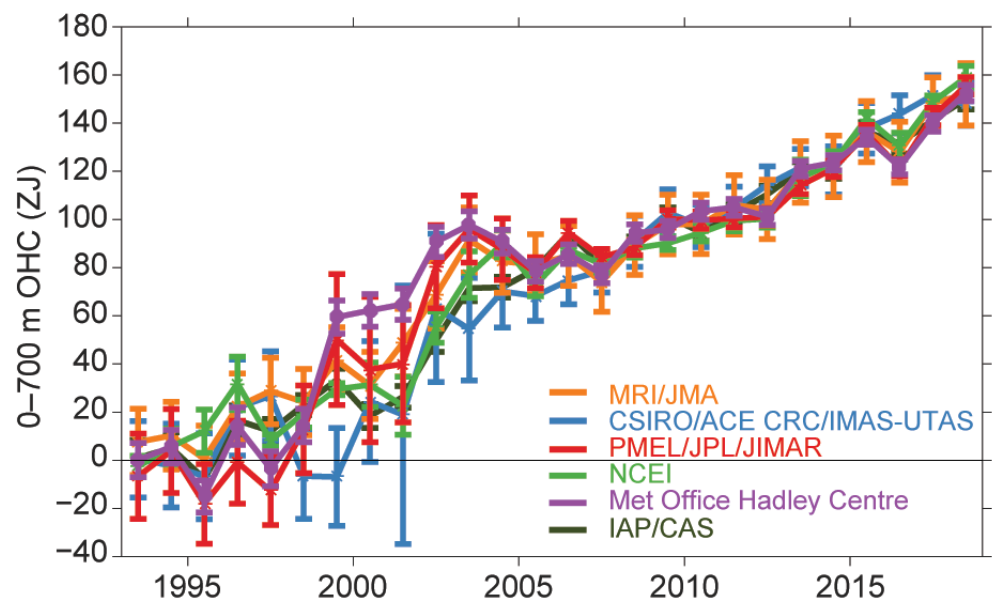

The global oceans serve as the memory of the climate system up to millennial time scales. They absorb, store, and transport energy through their depth and across longitude and latitude. Upper ocean heat content (UOHC) - the amount of energy stored in the top $700 \mathrm{~m}$ of the ocean-is one of the definitive measurements of cumulative change in the ocean. Six UOHC datasets indicate large increases since the late twentieth century; five of the six indicate that 20I8's UOHC was the largest annual value of the record, despite sea surface temperature cooling slightly in 2018 . (Figure 3.6a in State of the Climate in 2018 , see discussion there in section $3 c$.) 


\section{Sea surface salinity trends since 2005}

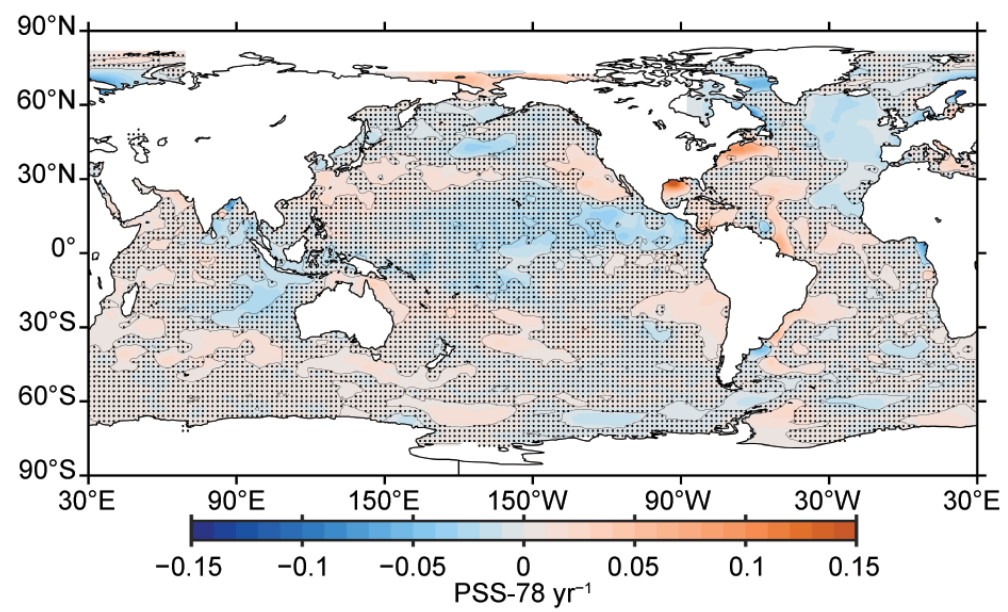

The hydrological cycle is accelerating globally. Over the oceans, this manifests in sea surface salinity anomaly patterns: dry regions are becoming drier and saltier, and wet regions rainier and fresher. The upper $600 \mathrm{~m}$ of the Atlantic has steadily become saltier from 2005 to $2018 ; 2018$ is the first year with all monthly salinity anomalies in the upper $1500 \mathrm{~m}$ of the Atlantic saltier than the long-term mean. (Figure 3.7c in State of the Climate in 2018, see discussion there in section 3d.)

at a cost of increased acidification of surface and subsurface waters.

THE TROPICS. Across the tropics, a total of 95 named tropical storms were observed during 2018, well above the 1981-2010 average of 82 . Eleven tropical cyclones reached the SaffirSimpson scale Category 5 intensity level-Super Typhoons Yutu, Mangkhut, Maria, Trami, Jebi, and Kong-Rey in the western North Pacific; Hurricanes Lane, Walaka, and Willa in the eastern North Pacific; Severe Tropical Cyclone Marcus in the Australian basin; and Hurricane Michael in the North Atlantic. This was only one less than the record of 12 Category 5 tropical cyclones in 1997.

In the North Atlantic basin, Major Hurricane Michael's landfall intensity of discussion there in section $4 f$.)
$140 \mathrm{kt}$ was the fourth strongest for any continental U.S. hurricane landfall in the 168-year record. Michael was responsible for over 30 fatalities in the United States and \$15-\$20 billion (U.S. dollars) in damages. In the western North Pacific, Super Typhoon Mangkhut led to $160 \mathrm{fa}$ talities and $\$ 6$ billion (U.S. dollars) in damages across the Philippines, Hong Kong, Macau, mainland China, Guam, and the Northern Mariana Islands. Tropical Storm Son-Tinh was responsible for 170 fatalities in Vietnam and Laos. Nearly all the islands of Micronesia experienced at least moderate impacts from various tropical cyclones.

THE ARCTIC. Considering latitudes above $60^{\circ} \mathrm{N}$, the 2018 Arctic land surface temperature was $1.2^{\circ} \mathrm{C}$ above the 1981-2010 average, tied as the third highest in the 118-year record, following only 2016 and 2017. Across Greenland, however, regional summer temperatures were generally below or near average, resulting in record high albedo for the entire ice sheet. Additionally,

\section{Tropical cyclone tracks and intensities for the hemispheric seasons ending in 2018}

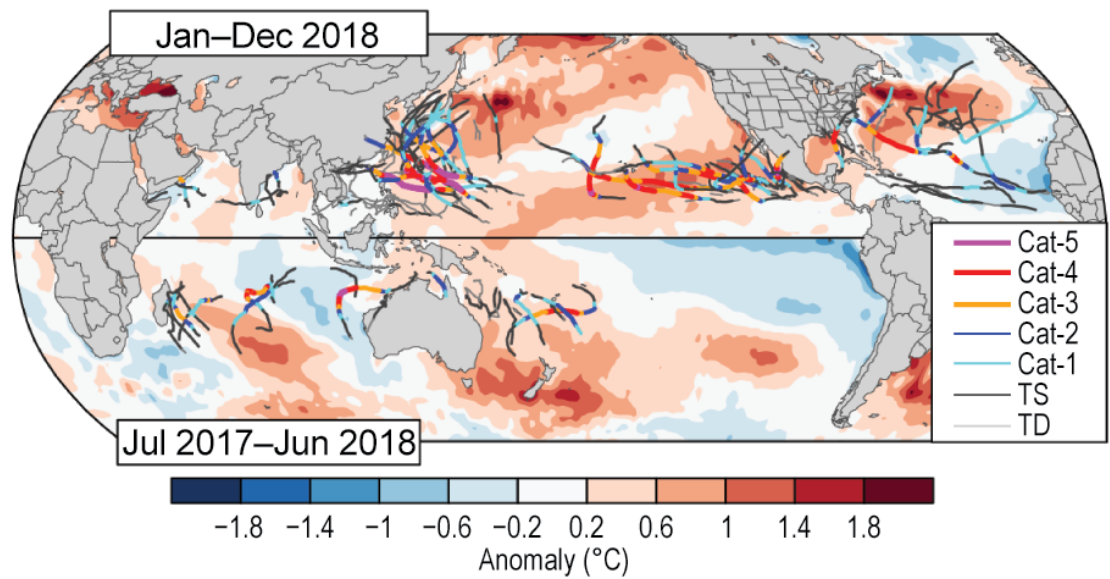

Each Northern Hemisphere tropical cyclone basin was above its 1981-2010 average for Accumulated Cyclone Energy (ACE) during the 2018 season. The eastern North Pacific set a new basin record for ACE. The North Atlantic basin had an ACE of nearly 145\% of its 198I-2010 median value. Both the North and South Indian Ocean were above their median ACE value. Only the southwest Pacific and Australian basins were below average for the Southern Hemisphere's 2017/I8 season. (Figure 4.16 in State of the Climate in 2018, see 


\section{Decline in Bering Sea ice extent in recent years}
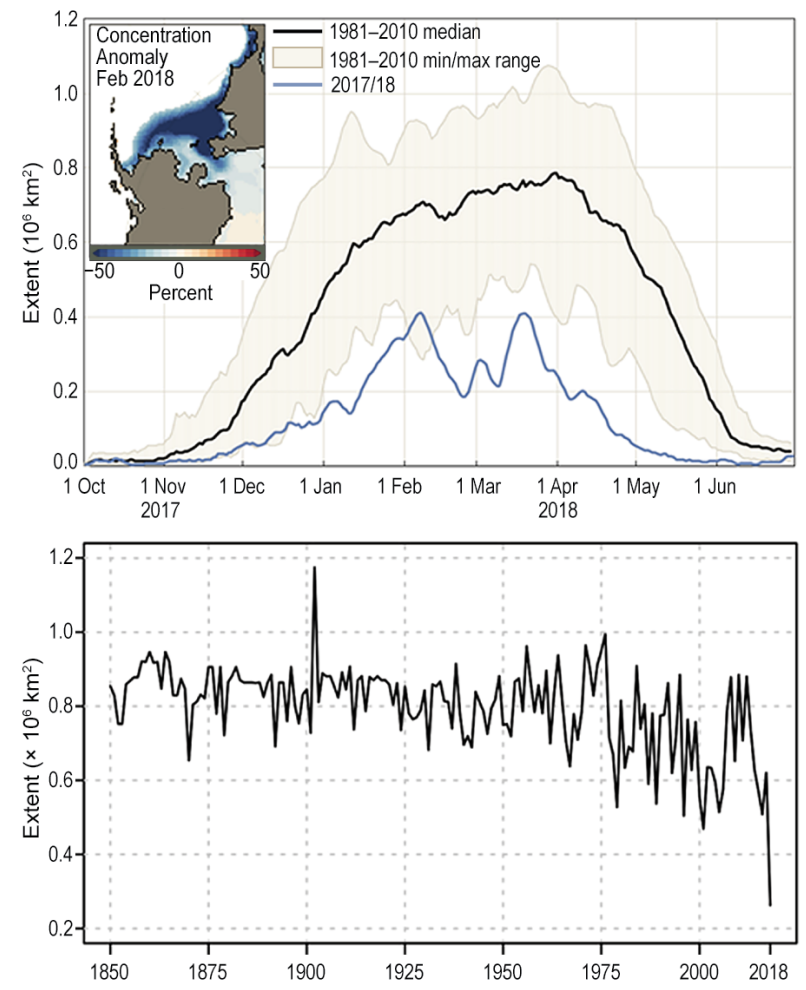

The Bering Sea, which separates Alaska and Russia roughly south of the Arctic Circle, witnessed significant reductions in sea ice during the October-June 2017/18 sea ice season, leading to record low ice extent for almost the entire ice season. The lack of ice influenced regional ecosystems and communities that depend on the ice as a protective barrier against winter storm surges and as a platform for hunting and travel. (Figure 5.1I in State of the Climate in 2018, see discussion there in section $\mathbf{5 d}$.)

an annual satellite survey of 47 marine-terminating glaciers in Greenland indicated a positive cumulative net area change for the first time since records began in 1999. Overall, the scale and pattern of rising Arctic surface air temperatures are major indicators of global climate change and drivers of widespread change in the Arctic environment.

On 17 March, Arctic sea ice extent at the end of the growth season was the second smallest maximum in the 38-year satellite record, larger than only 2017. First-year ice now dominates the ice cover and composed $\sim 77 \%$ of the March 2018 ice pack compared to about $55 \%$ during the 1980 s. Because thinner, younger ice is more vulnerable to melting out in summer, this shift in sea ice age has contributed to the decreasing trend in minimum ice extent. The minimum extent in 2018 was reached twice — on 19 September and again on 23 September-tying as the sixth lowest extent on record. The average rate of sea ice extent decline in September for the entire Arctic Ocean is now $-12.8 \%$ per decade. Over Arctic land, terrestrial snow cover shows overall declines in extent and snowmelt water equivalent over the past five decades. On average, Arctic snow cover extent during June was almost half of what it was 35 years ago, a loss rate close to the decline of the September sea ice extent. Beneath the surface, increasing permafrost temperatures were reported at most observation sites in the Arctic, with record high temperatures at 20-m depth at all sites on the North Slope of Alaska. The permafrost temperature increase of $0.1^{\circ}-0.2^{\circ} \mathrm{C}$ between 2017 and 2018 was comparable to the highest rate of warming observed in this region.

ANTARCTICA. In the Antarctic, 2018 was warmer than average for the continent as a whole, particularly near the South Pole, Dronning Maud Land, the Ross Ice Shelf, and Ross Sea. On the highest points of the Antarctic Plateau, the automatic weather station, Relay, broke or tied six monthly high temperature records throughout the year, with the August record broken by nearly $8^{\circ} \mathrm{C}$. However, cool conditions in the western Bellingshausen Sea and Amundsen Sea sector contributed to a low melt season overall for 2017/18, with the third smallest melt extent and fourth lowest melt intensity in the 41-year satellite record. This low-melt year continues a trend, now spanning from the $1978 / 79$ to $2017 / 18$ seasons, of reduced summer melting.

High SSTs contributed to low summer sea ice extent in the Ross and Weddell Seas in 2018, which led to the second lowest Antarctic summer minimum sea ice extent on record. Overall, sea ice extent has been below the 1981-2010 average since mid-September 2016. Throughout the year, 28 days of record low daily sea ice extent were observed, including 17 in December alone. The monthly mean sea ice area for December $\left(5.5\right.$ million $\mathrm{km}^{2}$ ) was the lowest for that month ever recorded.

Despite conducive conditions for its formation, including below-average temperatures and a stable polar vortex, the Antarctic stratospheric ozone hole at its maximum extent was near the mean for 2000-18, likely due to an ongoing slow decline in stratospheric chlorine monoxide concentration. The hole persisted until early December.

REGIONAL CLIMATES. North America. Annual temperatures across North America were above average across much of the continent for 2018, with 
below-average conditions across central and eastern Canada, and parts of the north-central contiguous United States. Mexico was the only country that had a top 10 warm year, with 2018 ranking the third warmest in the 48-year record, behind only 2016 and 2017 . Canada reported its 29th warmest year since records began in 1948 , while the United States had its 14th warmest in the 114-year record. The annual temperature across the continental United States has been increasing at an average rate of $0.08^{\circ} \mathrm{C}$ per decade since the start of the record, but at a rate nearly four times that $\left(0.3^{\circ} \mathrm{C}\right.$ per decade $)$ since 1970. Outside of the continental United States, Alaska observed its second warmest year, behind 2016, since its records began in 1925.

Annual precipitation totals were near average in western and eastern Canada, but seasonally, most stations in British Columbia were wetter than average during winter 2017/18 and drier-than-average during the spring and summer. The dry and warm conditions across British Columbia during late spring were associated with the most severe wildfire season in its history. Precipitation varied across Mexico throughout the year but on balance was $103 \%$ of average. Twelve tropical cyclones impacted Mexico in 2018, resulting in the country's most active season on record and contributing to wetter-than-average conditions across much of the nation during late September-October, the peak of the tropical cyclone season. Annually averaged precipitation across the continental United States was $112 \%$ of average, making 2018 its third wettest year on record. In Hawaii, $1262 \mathrm{~mm}$ of rain was recorded at Waipā Gardens (Kauai) on 14-15 April, setting a new U.S. record for 24-h precipitation. Across the continental United

\section{Hurricane Michael landfall in Florida's panhandle}

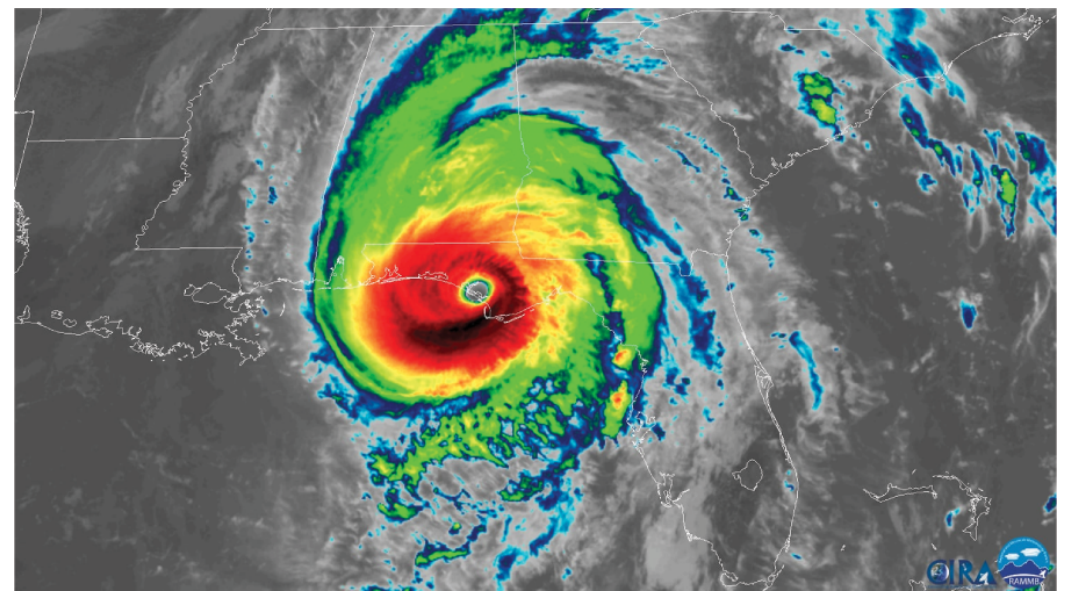

Hurricane Michael intensified rapidly approaching the Florida Gulf Coast in October. It was the most intense tropical cyclone to make landfall in the United States since 1992, and the most intense for the Florida Panhandle since accurate records began in the late 1800 s. Michael and Florence, which made landfall in the Carolinas in September, each caused roughly $\$ 25$ billion (U.S. dollars) in direct losses but were quite different in their character. Florence was a slow-moving storm upon landfall and caused tremendous inland flooding. Michael, in contrast, was a fast-moving storm that did substantial wind damage many miles inland. (Figure SB4.2 in State of the Climate in 2018, see discussion there in Sidebars 4.1 and 4.2 , and section $7 b$.)

\section{Sargassum bloom in the tropical North Atlantic and Caribbean Sea}

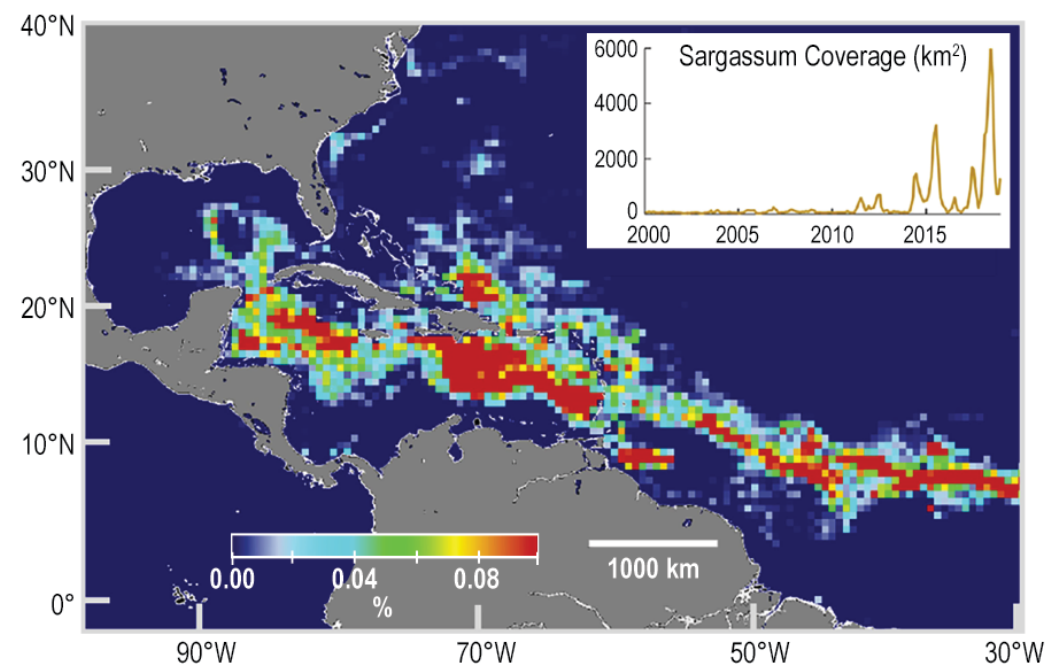

Two types of harmful blooms, Sargassum, shown here, and $K$. Brevis, known for causing "red tide," affected the waters in and around the Caribbean at significantly increased geographical range for much of 2018 . Each organism, when in expansive bloom, can cause significant stress to ecosystems and economic losses across tourism, and recreational and commercial fisheries. $K$. Brevis can additionally pose human health concerns. (Figure SB3.I in State of the Climate in 2018, see discussion there in Sidebars 3.I and 3.2.) 
States, there were 14 weather and climate events during the year that each caused over $\$ 1$ billion (U.S. dollars) in damages-the fourth highest in terms of cost since records began in 1980. Wildfires burned 3.5 million hectares in the United States in 2018. Wildfire costs in the United States have increased exponentially over the 2017 and 2018 wildfire seasons, with combined costs exceeding $\$ 40$ billion (U.S. dollars).

Central America and the Caribbean. In 2018, most of the Caribbean basin observed above-average annual mean surface temperatures, particularly notable toward the northwest and the Guianas, with Jamaica and northern Bahamas at least $0.75^{\circ}-1.5^{\circ} \mathrm{C}$ warmer than average. In contrast, parts of the southern and eastern Caribbean experienced below-average annual mean temperatures. The annual average maximum temperature of $32.3^{\circ} \mathrm{C}$ observed in Jamaica was the highest since records began in 1971, while the Bahamas reported its fifth highest annual average maximum temperature since $1971-29.8^{\circ} \mathrm{C}$. Conversely, the annual average maximum temperature for Barbados was its third lowest since 1971 at $29.6^{\circ} \mathrm{C}$.

Tropical cyclone activity during 2018 was low in the Caribbean basin and in the eastern tropical $\mathrm{Pa}$ cific. Four systems reached tropical storm category in the Caribbean basin: Alberto (26 May), Isaac (14-15 September), Kirk (29 September), and Michael (8 October). At the Grantley Adams International Airport in Barbados, Tropical Storm Kirk dropped a record 24-h rainfall total of $242.2 \mathrm{~mm}$ on $27 \mathrm{Sep}$ tember. Flooding, disruption to telecommunication services, and power outages all occurred. Michael evolved from a low-pressure system in the Caribbean that affected the region with heavy rains and accompanying impacts in most of Central America.

However, for the Caribbean as a whole, 2018 was drier than normal, with drought conditions reported for some islands. Below-normal rainfall in January-March was observed over most of the region. By summer and early autumn, severely dry conditions were noted over many of the islands, suggesting an intensification of drying relative to the first half of the year. Southern Hispaniola, northwestern Jamaica, Cuba, and the northern Bahamas also experienced some level of dryness. Record minimum annual rainfall totals were recorded at Hondo Valle and Villa Vásquez in the Dominican Republic, at $559.2 \mathrm{~mm}$ and $288.7 \mathrm{~mm}$, respectively. Short-term drought conditions were reported for some Caribbean islands, including the Bahamas, Cuba, Dominica, Hispaniola, St. Lucia, Tobago, and Martinique. Drought conditions in Antigua impacted water availability and vegetation.

\section{Coral reef bleaching in and around the Caribbean during 2018}
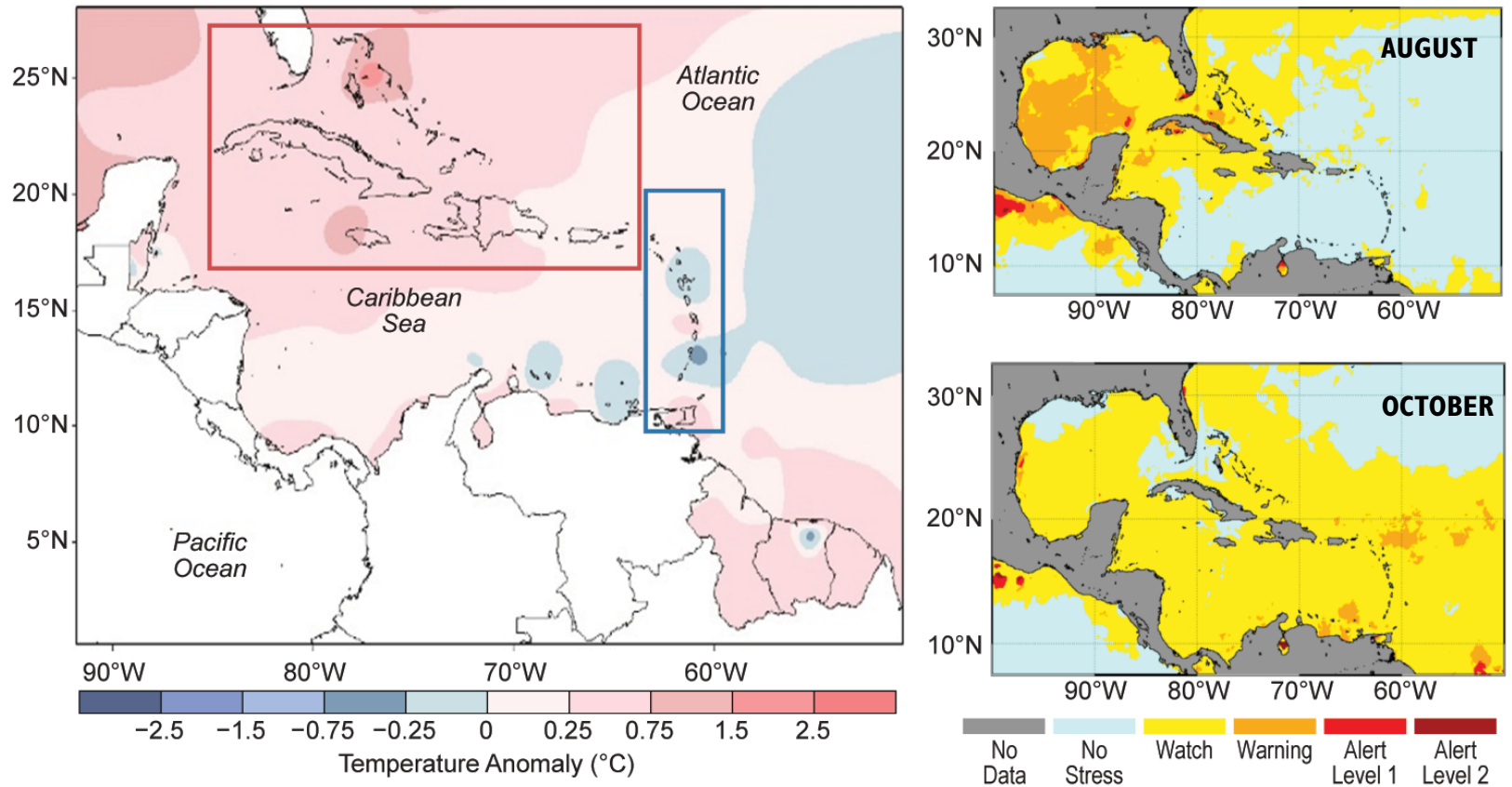

Coral reef bleaching associated with anomalously warm SSTs, occurred across much of the Caribbean during July-September 2018. (Figure 7.9 in State of the Climate in 2018, see discussion there in section 7c.) 
South America. Most of South America had above-average temperatures during 2018. In northern South America, some locations across eastern Venezuela and Guyana had annual maximum temperatures more than $+2.5^{\circ} \mathrm{C}$ above average. However, there were also notable extreme cold events in other parts of the continent during the year. Argentina and Uruguay each experienced their coldest (austral) winter since 2007. In the Peruvian Andes, several cold episodes occurred from June through September, resulting in one of the coldest winters in recent decades. On 4 June, a cold front brought cold temperatures to southern Brazil, with several locations setting new minimum temperature records. The front extended toward Bolivia and Peru, causing below-freezing temperatures in Peru's southern Andes that affected over 32,000 people. Another cold front on 15 June affected the Bolivian and Peruvian Amazon, with several locations reporting temperatures more than $10^{\circ} \mathrm{C}$ below average. A state of emergency was declared on 22 June for 122 districts in the southern Peruvian Andes due to the impact of frost and snowfall.

During 2018, both wet and dry precipitation extremes were observed across the continent. On 15 February, heavy rainfall in Rio de Janeiro, Brazil, caused deadly floods and affected public transportation and energy supplies; the city received $75 \%$ of its normal February precipitation total in just nine hours. In mid-April, copious rain fell in western Colombia, with $98.5 \mathrm{~mm}$ recorded in a 2 -h period, causing rivers to rapidly overflow near Cali. On 8 May, $78 \mathrm{~mm}$ of rain fell in one hour in Machala, Ecuador, causing flooding and landslides. Drierthan-average conditions were particularly notable across Chile, southern Peru, southern and western parts of Argentina, and across parts of eastern Brazil during the year. In northeastern Brazil, dry conditions observed since 2012 persisted through 2018, but with less intensity. In southeastern Brazil, São Paulo experienced its driest austral summer since 2003. The extreme dry conditions led to wildfires that affected

\section{Snowfall events in the Peruvian Andes}

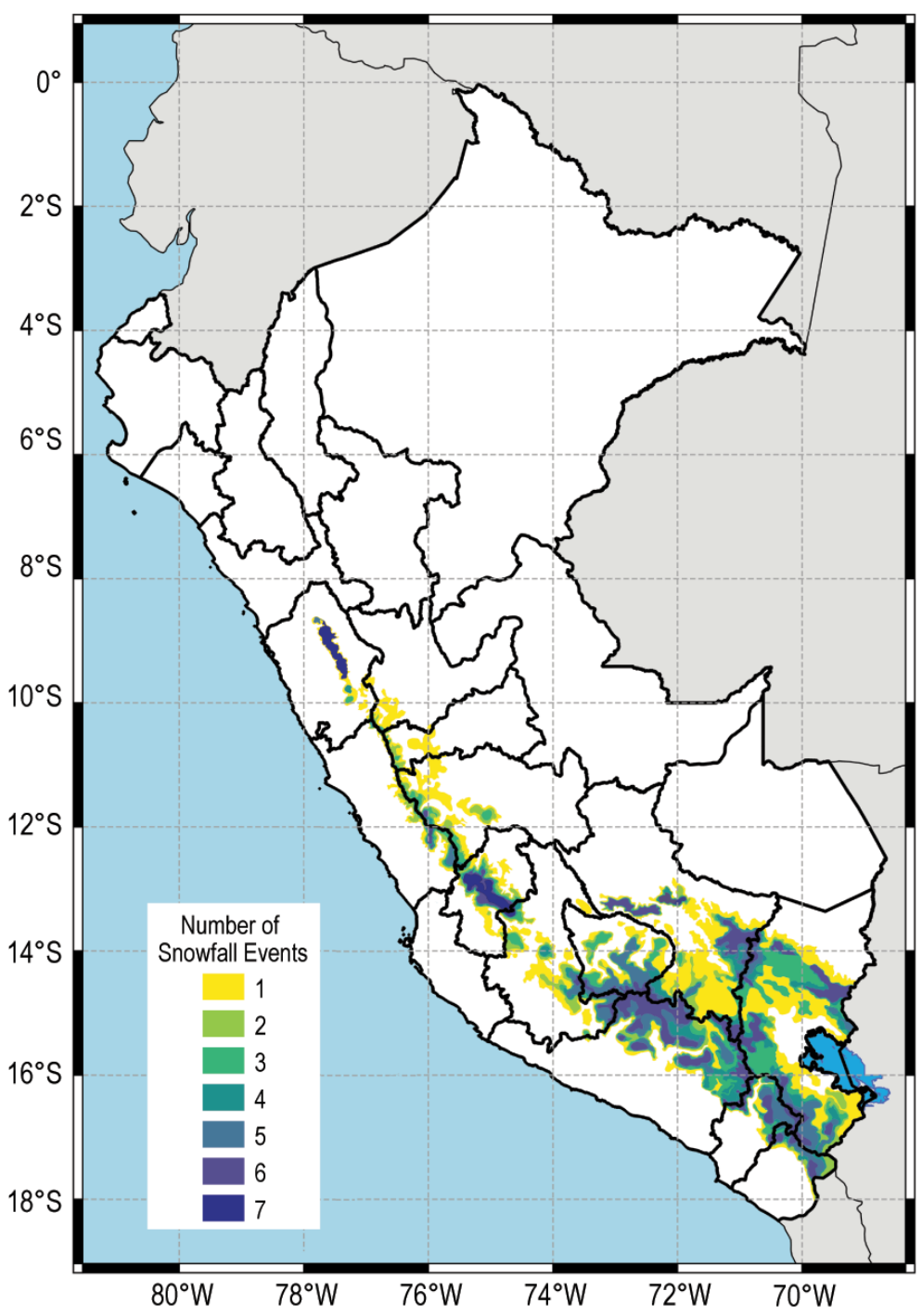

A record seven extreme snowfall events occurred in the central and southern Peruvian Andes during the austral winter of 2018. These storms contributed to the wettest winter for the region in the 19-year record. Typically no snow events occur in June, but the three episodes in $\mathbf{2 0 1 8}$ were the most among all months of the last 19 years. (Figure SB7.4 in State of the Climate in 2018, see discussion in Sidebar 7.2.)

crop fields and protected areas. Precipitation totals between January and March across much of central Argentina and Uruguay were as much as 50\%-85\% below normal. October 2017-March 2018 was the driest period on record for a large part of central Argentina, contributing to its most severe drought in the last five decades with estimated losses around $\$ 6$ billion (U.S. dollars).

Africa. In 2018, most of northern, eastern, equatorial, and southeastern Africa experienced above-normal 
temperatures, with below-normal temperatures recorded over Morocco and in pockets of West Africa. South Africa and the nearby Indian Ocean island nations of Mauritius, Réunion, and Mayotte all observed one of their four warmest years on record. Madagascar recorded its all-time maximum temperature of $40.5^{\circ} \mathrm{C}$ in Morondava on $16 \mathrm{March}$. In northern Africa, during July and August, Morocco and Algeria both experienced a succession of heat waves, with temperatures exceeding $40^{\circ} \mathrm{C}$. On 5 July, the temperature reached $51.3^{\circ} \mathrm{C}$ at Ouargla, Algeria, a new national record for the country.

South Africa was impacted by severe drought conditions, limiting soy and maize crops, among other major impacts. In other areas, however, precipitation was abundant. Record rainfall (150\%-200\% of average) in March and April caused flooding in Kenya, Somalia, southern Ethiopia, and northern and central Tanzania. Garissa station in Kenya recorded $125 \mathrm{~mm}$ of rainfall in a single day on 17 April, well above its average for the month. The torrential rains damaged infrastructure, including railways, which limited access to many of the affected areas. In Nigeria, heavy rainfall on 15 July caused the Niger and Benue Rivers to top their banks, flooding the surrounding areas and leading to 48 fatalities.

Annual precipitation was above normal in northern Madagascar and the Mascarene Islands (Réunion, Mauritius, and Rodrigues); Rodrigues and Réunion each reported their third wettest year on record. The wet conditions were related to more northerly winds and fewer trade winds during the rainy season, coupled with the influence of tropical storms that also damaged several regions. In early January, Tropical Cyclone Ava contributed to heavy rainfall and flooding in Mauritius, including a 24-h rainfall total of $311 \mathrm{~mm}$. Madagascar was also majorly affected, when Ava made landfall on 5 January near Toamasina. The storm caused 29 fatalities as well as flooding. Thirty-four people were killed when a tropical depression struck northern Nampula Province in Mozambique on 17 January. During mid-March, Tropical Storm Eliakim affected Madagascar, causing 17 fatalities and bringing rainfall totals as high as $388 \mathrm{~mm}$ (Sainte Marie).

Europe and the Middle East. Europe was one of the hotspots for the globe in 2018. The continent observed its second warmest year since at least 1950, behind only 2014 , with an anomaly of $+1.1^{\circ} \mathrm{C}$. Several countries, including France, Italy, Serbia, Croatia, Greece, and Bosnia and Herzegovina, reported record high annual temperatures, while many more observed one of their five warmest years on record. While it was a warm year overall, February and March were exceptionally cold across much of the continent due to a high-pressure system over Scandinavia, which resulted in easterly winds ushering in cold Siberian air in February and the Icelandic Low located close to Ireland in March. Seasonally, spring was exceptionally mild for most of Europe, due to an extended high-pressure influence that lasted until September. In April and May, many stations across central and northern Europe reported new record daily maximum temperatures, often by a wide margin. Summer 2018 was one of the five warmest summers on record for a number of countries, including the Netherlands and Belgium. In July, a monthly average temperature of $22.5^{\circ} \mathrm{C}$ was recorded for Stockholm, the highest monthly temperature ever recorded in Sweden. During 24 July-8 August, France experienced a heat wave with temperatures locally exceeding $40^{\circ} \mathrm{C}$. Warmth continued in autumn. In European Russia, October was the warmest on record since 1891. In Romania, October tied as the second warmest since its record began in 1961. For the first time in many parts of Moldova, the monthly maximum temperature reached $24^{\circ}-27^{\circ} \mathrm{C}$ in October.

Much of northern and central Europe experienced a dry year with precipitation totals $60 \%-80 \%$ of normal, and even below $40 \%$ in Latvia and Estonia, contributing to a drought that lasted much of the year. The Netherlands reported one of its driest summers since records began in 1906, with July its driest month ever observed. Ireland also reported its driest summer since its records began in 1962, with June and July each record dry. The extreme heat and severe drought across Europe had far reaching impacts on water supply, forests, and crops, leading to major economic losses in many countries. Lithuania and Latvia each declared a state of emergency. In Germany, the drought caused related damages of at least $\$ 3.4$ billion (U.S. dollars). Sweden and Greece reported large and unprecedented wildfires, especially in July. Record low water levels in major rivers such as the Rhine and Danube hindered the transport of goods; some industrial firms and power plants were forced to reduce or even temporarily shut down their production due to cooling water being too warm or unavailable.

There were some wet areas as well. Winter was wet especially in the Balkans. Serbia and Slovenia each reported their fourth wettest winter with precipitation $160 \%-170 \%$ of normal. In early summer, multiple cyclones crossed southern Italy and the southeastern Balkans, bringing heavy precipitation. In Greece, Argostoli received $83.5 \mathrm{~mm}$ of precipitation during 26-27 June, which is 12 times its monthly normal. 


\section{European continent experiences second warmest year}

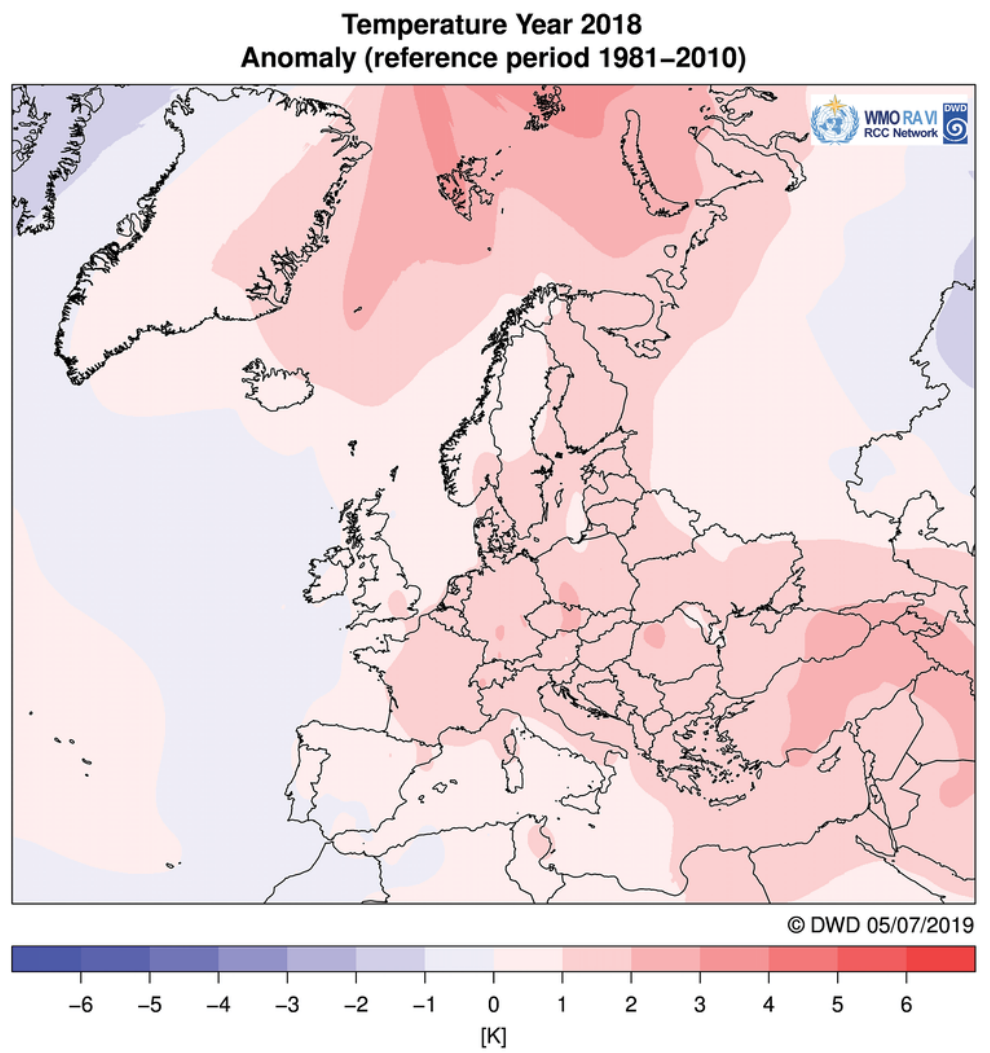

All of Europe was warmer than average during 2018 , as shown by the annual temperature anomalies in the map above. Overall, it was the second warmest year on record for the continent since at least 1950. (Figure 7.34 in State of the Climate in 2018, see discussion there in section $7 f$.)

Asia. Annual mean surface air temperatures during 2018 were above normal across most of Asia. Overall, Turkey observed its second warmest year, after 2010, with records dating back to 1967. In India, the pre-monsoon season (March-May) anomaly of $+0.55^{\circ} \mathrm{C}$ was the highest on record. In neighboring Pakistan, the city of Nawabshah recorded its highest temperature of $50.2^{\circ} \mathrm{C}$, which may also be a new world temperature record for April. Russia reported its second warmest autumn on record. In October, temperatures were as much as $9^{\circ}-10^{\circ} \mathrm{C}$ above average in north central Siberia.

During the South Asian pre-monsoon, monsoon, and post-monsoon seasons, flood- and heavy rainrelated incidents claimed over 800 lives across parts of India. The Iduki district received an all-time record three-day rainfall of $710.2 \mathrm{~mm}$ on 15-17 August.

An unusual northward shift of the western North Pacific subtropical high led to a deficient East Asian summer monsoon (EASM) rainfall and a severe heat wave from north China, across the Korean Peninsula, to eastern Japan. The EASM in 2018 was the weakest recorded in the past 40 years. In South Korea, the annual rainy season-called Changma-lasted only 14-16 days, which is the second shortest Changma since 1973. South Korea also experienced a record hot summer. The maximum temperature in Seoul on 1 August was $39.6^{\circ} \mathrm{C}$, which was the city's highest since records began in 1907. The highest temperature ever recorded in South Korea was also set on the same day: $41.0^{\circ} \mathrm{C}$ in Hongcheon. In mid-July, an all-time national record high temperature of $41.1^{\circ} \mathrm{C}$ was set at Kumagaya, Saitama prefecture in Japan.

Tropical cyclones affected several regions across coastal Asia. In China, 10 typhoons made landfall during 2018 , three more than normal. For the year, 83 people were reported dead or missing, and there was approximately $\$ 10$ billion (U.S. dollars) in direct economic losses. During July and August, three destructive tropical cyclones (Ampil, Jongdari, and Rumbia) struck Shanghai City, along China's central coast, within one month, an unprecedented occurrence. Prior to this, only six tropical cyclones in total had made landfall in Shanghai City since 1949. Severe Typhoon Mangkhut struck Hong Kong on 16 September, bringing severe storm surge and heavy rain squalls that caused the most extensive damage to Hong Kong since Typhoon Ellen in 1983. In September, Typhoons Jebi and Trami struck western Japan, causing damage from windstorms and storm surge flooding. In October, Typhoon Kong-rey made landfall over South Korea, contributing to a record high precipitation total of $164.2 \mathrm{~mm}$ for the month.

Oceania. A busy tropical cyclone season for the northwest Pacific brought a number of extreme rainfall events across the region. Nearly all the islands of Micronesia experienced impacts from various tropical cyclones: Jelewat in March; Maria in July; Cimaron and Jebi in August; Manghkut, Trami, and Kong-rey in September; and Yutu in October. Typhoon Jelawat brought over $500 \mathrm{~mm}$ of rainfall in two days to parts of Pohnpei Island. Typhoon Mangkhut passed over Rota in the Commonwealth of the Northern Mariana Islands (CNMI) and northern Guam in September, 


\section{Rainfall associated with Tropical Cyclone Josie and Keni around the Fiji Islands}
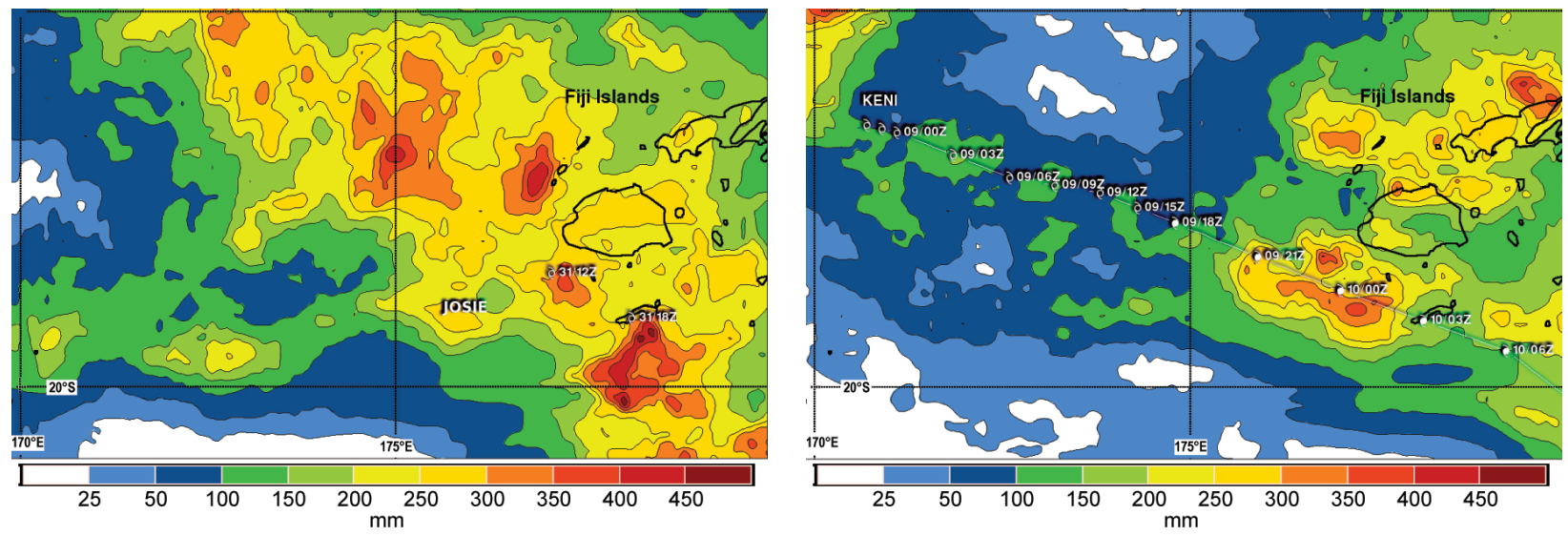

Rainfall and storm surge associated with Tropical Cyclones Josie (top) and Keni (bottom) caused significant flooding and damaging winds to several Fijian islands during late March and early April. (Figures 7.52 and 7.53. in State of the Climate in 2018, see discussion there in section $7 \mathrm{~h} 3$. )

\section{Australia experiences third lowest rainfall during its cold season}

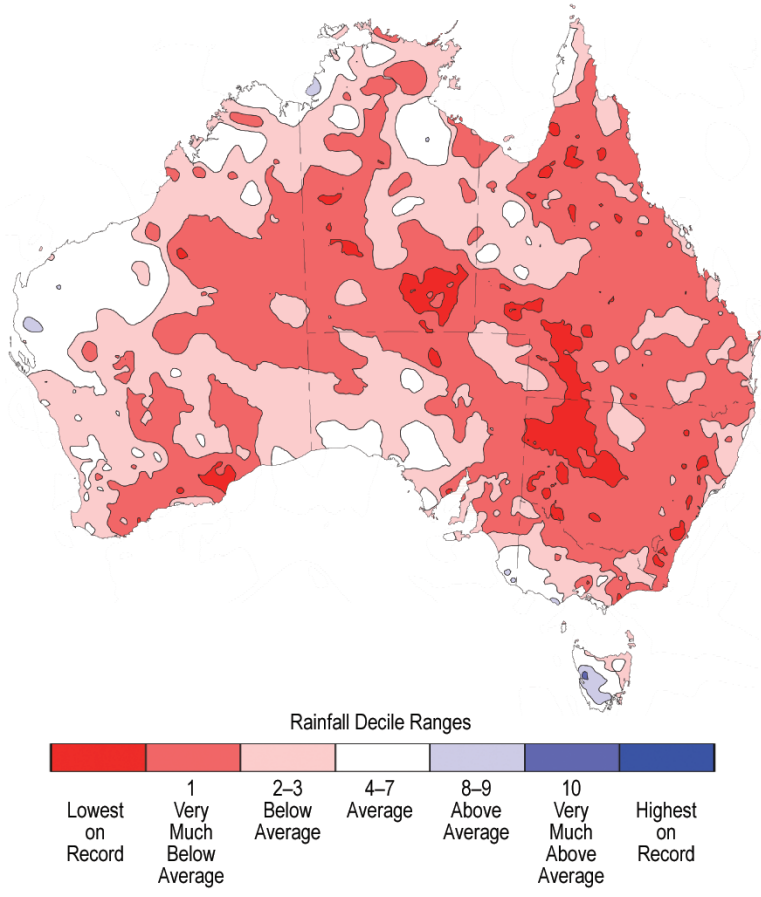

For the April-September period, rainfall was the third lowest on record for Australia. Nationally, September was the driest on record for the month, and the second driest for any month on record behind only April 1902. (Figure SB7.9 in State of the Climate in 2018, see discussion there in Sidebar 7.5.) and Super Typhoon Yutu passed over Tinian and Saipan in the CNMI in October, each causing catastrophic damages.

A notable marine heatwave with SSTs $2^{\circ}-4^{\circ} \mathrm{C}$ above average in the Tasman Sea and New Zealand coastal waters from November 2017 to February 2018 likely contributed to warmer weather early in the year for both countries. January 2018 marked New Zealand's warmest single month on record. Overall, the 2018 annual temperature for the country was $0.80^{\circ} \mathrm{C}$ above the 1981-2010 average, tying with 1998 as the second highest since records began in 1909, behind only 2016.

Summer-like warmth followed January heatwaves in southeastern Australia, with early-April heat waves setting many records across southern Australia. Warmth continued and was widespread and persistent through the year-the national monthly mean temperature was among the 10 highest on record for January, February, March, April, July, October, and December. The annual mean temperature for Australia was $0.76^{\circ} \mathrm{C}$ above the $1981-2010$ average, the third highest on record. Australia also saw a rapid intensification and expansion of drought conditions during 2018. There were significant fires in March on the south coast of New South Wales and across southwest Victoria. Rainfall for March-May was the second lowest on record for southern Australia, and by the second half of the year, the New South Wales government had declared $100 \%$ of the State to be in drought. From May through the end of the year, cooler-thanaverage waters to the northwest of Australia and parts of the eastern Indian Ocean may have contributed to the drought over central and southeastern Australia. 